\title{
Effect of tillage, residue and nitrogen management on radiation interception, radiation use efficiency and evapotranspiration partitioning
}

\author{
KOUSHIK BAG, K.K. BANDYOPADHYAY*, V.K. SEHGAL, A. SARANGI ${ }^{1}$ and P. KRISHNAN
}

Division of Agricultural Physics, ICAR-Indian Agricultural Research Institute (IARI), New Delhi-110012; ' Water Technology Centre, ICAR-IARI, New Delhi-110012

*Corresponding author: kk.bandyopadhyay@gmail.com

\begin{abstract}
In this study, we have evaluated the effect of different tillage (conventional tillage (CT) and no tillage (NT)), residue (with crop residue mulch $\left(R^{+}\right)$and without residue $(R 0)$ ) and nitrogen $(60,120$ and $180 \mathrm{kgN} \mathrm{ha}^{-1}$ ) interaction for radiation interception, radiation use efficiency (RUE), evapotranspiration (ET) partitioning and yield of wheat in a split-split plot design for 2017-18 and 2018-19. Results showed that Leaf Area Index (LAI), Leaf area duration (LAD), Total intercepted photosynthetically active radiation (TIPAR), Grain and Biomass yields were higher in $\mathrm{R}+$ during both the years of study. With increasing $\mathrm{N}$ doses LAI, LAD, TIPAR, RUE, grain and biomass yields increased and extinction coefficient decreased significantly in both the years. Fraction intercepted photosynthetically active radiation (fIPAR) followed a similar trend with LAI. Seasonal ET was partitioned into soil evaporation (Ep) and crop transpiration (Tp) to take into account the productive transpiration effects on crop growth and yield. It was found that NT and residue could reduce Ep (6\% and $5.6 \%)$ and increased $\mathrm{Tp}(2.6 \%$ and $2.4 \%)$ over CT and no mulch treatments, respectively. With higher N-dose, Ep decreased while Tp increased significantly. Thus besides higher nitrogen doses, NT and crop residue mulching could be a better strategy to harness higher radiation interception vis-a-vis higher crop productivity.
\end{abstract}

Key words : Conventional tillage, no tillage, LAI, RUE, soil evaporation, crop transpiration

Conventional agricultural practices involving indiscriminate tillage practices and imbalanced use of fertilizers and agrochemicals have become a matter of serious concern with respect to degradation of land resources, reduction of biodiversity and low efficiency of inputs (Boatmann et al., 2007). Conservation agriculture (CA), on the other hand, involving reduced tillage, residue retention and crop rotation have beneficial impacts on the global environment (soil, air, water and biodiversity) compared to traditional agriculture (Kassam et al., 2010). These practices along with other best management practices like raised bed planting for water saving and better establishment offer particular opportunities in the maizewheat in South Asia (Fredrich and Gustafson, 2007). Das et al. (2018) reported that practicing conservation agricultural practices could improve the yield and water productivity in maize-wheat system in the Indo-gangetic Plain region. Therefore the conservation agriculture practices are targeted to achieve sustainability by implementation of management practices which would minimize environmental degradation and improve resource use efficiency. While most of the research focuses on the photosynthetic efficiency and harvest index of crops, literature on the modification of microclimate by changing management practices that can affect the yield is scanty (Pragya et al., 2018; Wakchaure et al., 2015 ).

With this background, the objective of this study was to explore the pattern of radiation interception and radiation use efficiency under different conservation agriculture treatments and comparing them with conventional practices. This study was also aimed at partitioning of evapotranspiration into utilizable (transpiration) and nonutilizable (evaporation) water resource used under conservation vis-à-vis conventional agricultural systems.

\section{MATERIALS AND METHOD}

\section{Experimental details}

The experiment was conducted for two consecutive years (2017-18 and 2018-19) on wheat cultivar HD-2967 at the ICAR-Indian Agricultural Research Institute, New Delhi $\left(28^{\circ} 37^{\prime} \mathrm{N}, 77^{\circ} 12^{\prime} \mathrm{E}\right)$ in rabi season $\left(24^{\text {th }}\right.$ Nov to $16^{\text {th }}$ April $)$. New Delhi is coming under sub-tropical semi-arid climate with a mean annual rainfall of $651 \mathrm{~mm}$. The surface soil $(0$ - 
$15 \mathrm{~cm}$ ) is sandy loam in texture, with an average bulk density of $1.58 \mathrm{Mg} \mathrm{m}$ "3; $\mathrm{pH} 7.8$ (1:2.5 soil: water suspension); organic $\mathrm{C}, 4.2 \mathrm{~g} \mathrm{~kg}^{-1}$; Total $\mathrm{N}$, available (Olsen) $\mathrm{P}$ and available K content of $0.032 \%, 7.1 \mathrm{~kg} \mathrm{ha}^{-1}$ and $281 \mathrm{~kg} \mathrm{ha"}{ }^{1}$, respectively.

The experiment was conducted in a split-split plot design with two levels of tillage i.e. Conventional tillage (CT) and No Tillage (NT) as main plot factor, two levels of residue mulching (maize residue @ 5 tha ${ }^{-1}(\mathrm{R}+$ ) and without residue (R0)) as sub plot factor, and three levels of nitrogen i.e. $50 \%\left(\mathrm{~N}_{60}\right), 100 \%\left(\mathrm{~N}_{120}\right)$ and $150 \%\left(\mathrm{~N}_{180}\right)$ of the recommended dose of nitrogen in wheat as sub sub-plot factor, which correspond to 60,120 and $180 \mathrm{~kg} \mathrm{~N} \mathrm{ha}^{-1}$, respectively. There were three replications and the size of sub-sub plot was $4.5 \mathrm{~m} \times 5 \mathrm{~m}$.

\section{Weather parameters}

The weather parameters were obtained from the agrometeorological observatory situated adjacent to the field. Different weather parameters like mean minimum and maximum temperatures, rainfall, morning and evening relative humidity, wind speed, bright sunshine hours and pan evaporation were recorded on daily basis.

\section{Crop parameters}

Plant samples ( $1 \mathrm{~m}$ row length) were collected from the fields at regular intervals to determine the temporal variation in plant biomass on dry weight basis (dried in oven at $70^{\circ} \mathrm{C}$ till constant weight) and expressed in $\mathrm{tha}^{-1}$.

\section{Leaf area index (LAI) and leaf area duration (LAD)}

LAI was measured in all the three replications using LAI- 2000 Plant Canopy Analyzer (LI-COR, USA) at weekly intervals (between 11:30 and 12:00 hours IST) for two consecutive years. LAD was computed using the following relationship:

$$
\mathrm{LAD}=\Sigma\left(\left(\mathrm{LAI}_{\mathrm{n}-1}+\mathrm{LAI}_{\mathrm{n}}\right) / 2\right)\left(\mathrm{t}_{\mathrm{n}}-\mathrm{t}_{\mathrm{n}-1}\right)
$$

Where, $\mathrm{LAI}_{\mathrm{n}}$ and $\mathrm{LAI}_{\mathrm{n}-1}$ correspond to LAI at sampling time $t_{n}$ and $t_{n-1}$, respectively.

\section{Grain and biomass yield}

Grain yield along with the harvest biomass was obtained at the time of crop harvesting from an area of $2 \times$ $2 \mathrm{~m}^{2}$ from each plot in three replications and the yield was expressed as $\mathrm{kg} \mathrm{ha}^{-1}$. The harvest biomass was obtained after air drying the plant obtained from that area.

\section{Radiation characteristics}

The photosynthetically active radiation (PAR) measurements were taken using Line quantum sensor LI191SA(LICOR Inc., Lincoln, NE, USA) (between 11:30 and 12:00 hours IST) from the top and bottom of wheat canopy on the same day when LAI observations were taken. The fraction intercepted photosynthetically active radiation (fIPAR) for a particular day is obtained from the following formula:

$$
\text { fIPAR }=(\text { Io-It }) / \text { Io }
$$

where, 'Io' is incident radiation and 'It' is transmitted radiation through the canopy.

Daily insolation was calculated using Angstrom equation (using coefficients $\mathrm{a}=0.32, \mathrm{~b}=0.46$ ), where bright sunshine hours observation was used as an input. Subsequently, incident PAR was calculated by multiplying a factor of 0.48 with the daily insolation values. Latter, daily intercepted PAR(IPAR) was estimated bymultiplying incident PAR with fIPAR. Similarly, total IPAR (TIPAR) was obtained by integration of daily IPAR. The radiation use efficiency (RUE) was calculated by dividing total above ground biomass $\left(\mathrm{g} \mathrm{m}^{-2}\right)$ with the TIPAR $\left(\mathrm{MJ} / \mathrm{m}^{2}\right)$ for the whole crop duration (Pradhan et al., 2014; Goyal et al., 2018).

The canopy extinction coefficient ( $\mathrm{k}$ ) was computed from fIPAR and LAI following Monsi and Saeki (1953) equation. .

Extinction coefficient was determined from the slope of the regression equation between LAI and $\ln (1$ - fIPAR), when it is forced through zero.

\section{Evapotranspiration}

The potential evapotranspiration $\left(\mathrm{ET}_{0}\right)$ was calculated as per Penman and Monteith equation, (Allen et al., 1998. Wheat crop ET (ETc) was estimated by multiplying crop coefficient (Kc, FAO 56) under standard well-watered, fertilized and disease-free conditions.

$$
E T 0=\frac{0.408 \Delta(R n-G)+\gamma \frac{900}{T+273} u 2(e 0-e a)}{\Delta+\gamma(1+0.34 u 2)}
$$

Where,

$\mathrm{ET}_{0}$ - potential evapotranspiration in $\mathrm{mm} / \mathrm{day} ; \mathrm{R}_{\mathrm{n}}-$ net radiation at crop surface $\left(\mathrm{MJ} \mathrm{m}^{-2} \mathrm{hr}^{-1}\right)$; G - soil heat flux density $\left(\mathrm{MJ} \mathrm{m}^{-2}\right.$ day $\left.^{-1}\right) ; \mathrm{T}$ - air temperature at $2 \mathrm{~m}$ height $\left({ }^{\circ} \mathrm{C}\right)$; $\mathrm{e}_{\mathrm{s}}$ - saturation vapour pressure $(\mathrm{kPa}) ; \mathrm{e}_{\mathrm{a}}$ - actual vapour pressure $(\mathrm{kPa}) ; \mathrm{u}_{2}$ - wind speed at $2 \mathrm{~m}$ height $\left(\mathrm{m} \mathrm{s}^{-1}\right) ; \Delta$ - the slope of the vapour pressure curve $\left(\mathrm{kPa}^{\circ} \mathrm{C}^{-1}\right) ; \gamma$ - The psychrometric constant in $\left(\mathrm{kPa}^{\circ} \mathrm{C}^{-1}\right)$. 

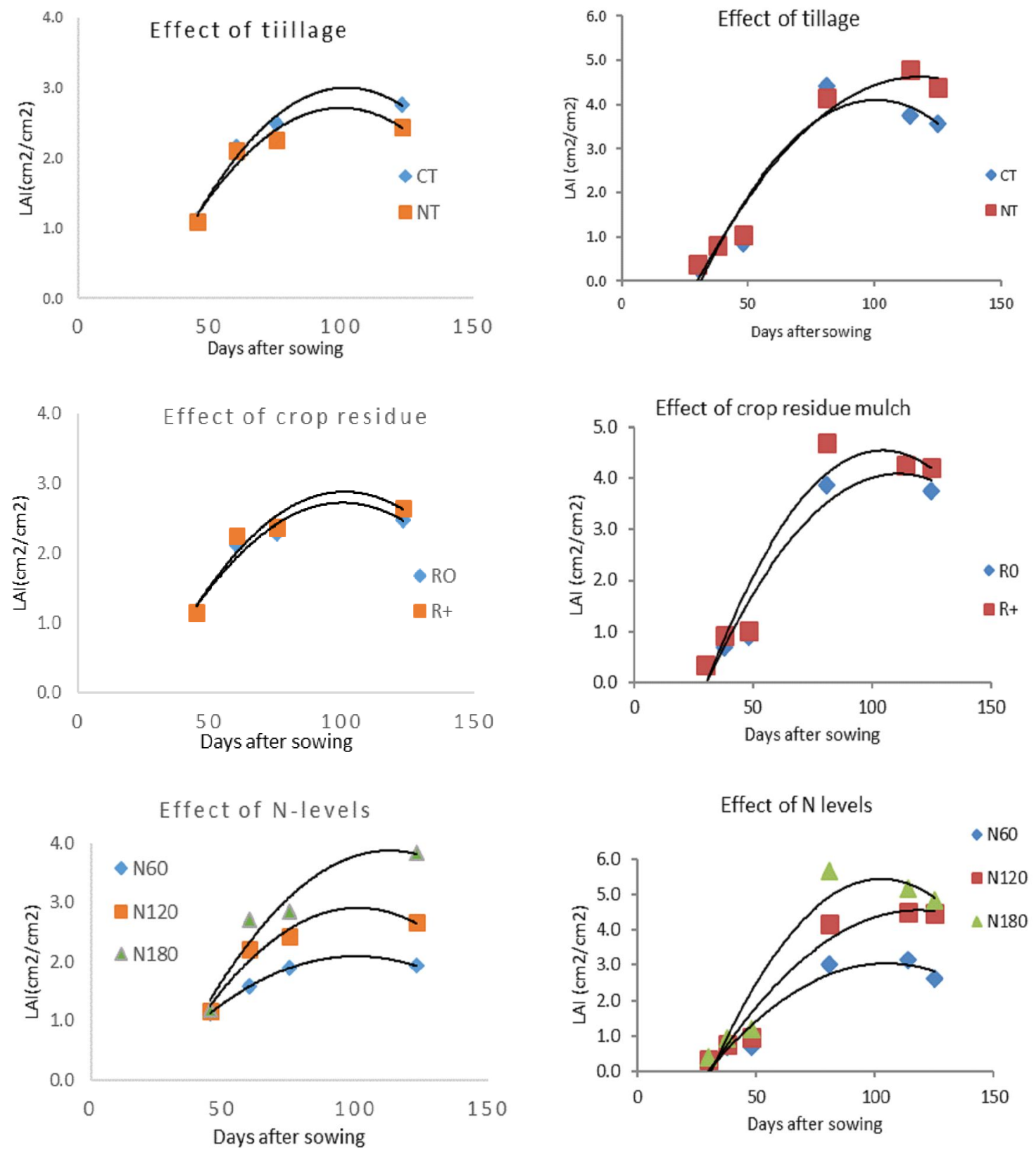

Fig.1: Leaf area index of wheat as influenced by tillage, residue and nitrogen management during the year 2017-18 and 2018-19.

The net radiation was evaluated from the following formula:

$$
\mathrm{R}_{\mathrm{n}}=(1 \gamma)(0.25+0.5 \mathrm{n} / \mathrm{N}) S O "(0.9 \mathrm{n} / \mathrm{N}+0.1)(0.34-
$$
0.14 "e $\left.\mathrm{e}_{\mathrm{a}}\right) \sigma \mathrm{T}$

Where,

$\mathrm{T}$ - the air temperature $(\mathrm{K})$; $\mathrm{r}$ - the reflection coefficient (observed mean value, 0.24 ); $\mathrm{n}$ - the number of hours of bright sunshine per day (h); $\mathrm{N}$ - The total day length (h); $S O$ is the extra-terrestrial radiation $\left(\mathrm{MJ} \mathrm{m}^{-2} \mathrm{day}^{-1}\right) ; \mathrm{e}_{\mathrm{a}}$ - the vapour pressure $(\mathrm{kPa}) ; \sigma$ - The Stefan-Boltzmann constant $\left(4.903 \times 10^{-9} \mathrm{MJ} \mathrm{m}^{-2} \mathrm{~K}^{-4}\right.$ day $\left.^{-1}\right)$

\section{Partitioning evapotranspiration}

For partitioning ETc into soil evaporation (Ep) and crop transpiration (Tp), the following formula (Ritchie 1972) was used,

$$
\mathrm{Ep}=E T c \cdot \exp (-k \cdot L A I)
$$

where, $\mathrm{k}$ is extinction coefficient. 
Table 1: Monthly weather data of the study area

\begin{tabular}{|c|c|c|c|c|c|c|c|c|c|c|c|c|c|c|}
\hline \multirow[b]{2}{*}{ Month } & \multicolumn{2}{|c|}{$\begin{array}{l}\text { Max. } \\
\text { temp. }\left({ }^{\circ} \mathrm{C}\right)\end{array}$} & \multicolumn{2}{|c|}{$\begin{array}{l}\text { Min. } \\
\text { temp. }\left({ }^{\circ} \mathrm{C}\right)\end{array}$} & \multicolumn{2}{|l|}{$\begin{array}{l}\text { Max. } \\
\text { RH(\%) }\end{array}$} & \multicolumn{2}{|l|}{$\begin{array}{l}\text { Min. } \\
\text { RH(\%) }\end{array}$} & \multicolumn{2}{|c|}{$\begin{array}{l}\text { Sunshine } \\
\text { hours }\end{array}$} & \multicolumn{2}{|c|}{$\begin{array}{l}\text { Rainfall } \\
(\mathrm{mm})\end{array}$} & \multicolumn{2}{|c|}{$\begin{array}{l}\text { Evaporation } \\
(\mathrm{mm})\end{array}$} \\
\hline & $\begin{array}{l}2017- \\
18 \\
\end{array}$ & $\begin{array}{l}2018- \\
19 \\
\end{array}$ & $\begin{array}{l}2017- \\
18 \\
\end{array}$ & $\begin{array}{l}2018- \\
19 \\
\end{array}$ & $\begin{array}{l}2017- \\
18 \\
\end{array}$ & $\begin{array}{l}2018- \\
19 \\
\end{array}$ & $\begin{array}{l}2017- \\
18 \\
\end{array}$ & $\begin{array}{l}2018- \\
19 \\
\end{array}$ & $\begin{array}{l}2017- \\
18 \\
\end{array}$ & $\begin{array}{l}2018- \\
19 \\
\end{array}$ & $\begin{array}{l}2017- \\
18 \\
\end{array}$ & $\begin{array}{l}2018- \\
19 \\
\end{array}$ & $\begin{array}{l}2017- \\
18 \\
\end{array}$ & $\begin{array}{l}2018- \\
19 \\
\end{array}$ \\
\hline Nov & 26.8 & 27.4 & 10.6 & 11.8 & 87.7 & 88.9 & 49 & 57.6 & 2.5 & 4.7 & 0.0 & 4.0 & 2.3 & 2.9 \\
\hline Dec & 23.0 & 21.8 & 6.8 & 5.0 & 87.0 & 94.7 & 51 & 63.8 & 4.5 & 4.4 & 0.0 & 0.2 & 2.3 & 2.0 \\
\hline Jan & 20.6 & 20.0 & 4.3 & 6.4 & 92.8 & 90.3 & 49.3 & 70.7 & 6.3 & 3.8 & 6.0 & 52.0 & 2.4 & 1.6 \\
\hline Feb & 24.9 & 21.3 & 8.4 & 10.0 & 80.2 & 95.0 & 41.9 & 74.6 & 6.4 & 3.6 & 0.0 & 72.2 & 3.5 & 1.9 \\
\hline Mar & 31.6 & 27.0 & 13.4 & 12.4 & 83.0 & 89.3 & 31.3 & 57.5 & 8.2 & 7.3 & 0.0 & 10.0 & 5.1 & 3.1 \\
\hline April & 36.5 & 37.2 & 19.9 & 21.1 & 62.3 & 71.8 & 29.8 & 42.0 & 7.7 & 8.2 & 20.0 & 5.7 & 6.0 & 5.3 \\
\hline
\end{tabular}

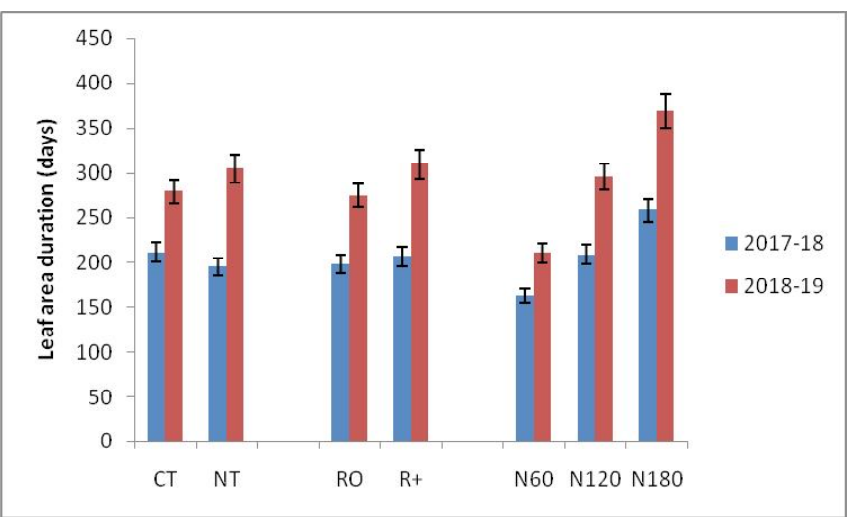

Fig.2: Leaf area duration of wheat as influenced by tillage, residue and nitrogen management.

Thereafter crop transpiration was calculated as $\mathrm{Tp}=(\mathrm{ETc}-\mathrm{Ep})$

\section{RESULTS AND DISCUSSION}

\section{Weather}

Monthly average maximum temperature, minimum temperature, maximum relative humidity, minimum relative humidity, bright sunshine hours, rainfall and evaporation during crop growth periods of wheat for the years 2017-18 and 2018-19 are presented in Table 1. The crop experienced a higher maximum temperature (December, January, February and March) in the year 2017-18 compared to the year 201819 by $1.2,0.6,3.6$ and $4.6^{\circ} \mathrm{C}$, respectively. During the year 2017-18, the crop received a total rainfall of $26 \mathrm{~mm}$ whereas, during the year 2018-19 the crop received a total rain of $144.1 \mathrm{~mm}$. The average sunshine hour during the year $2017-$ 18 (5.93 h) was higher than that of the year 2018-19 (5.33 h). The mean RH during the year 2018-19 (74.7\%) was higher than that of the year 2017-18 (62.1\%). So the crop during the year 2017-18 was under high temperature and moisture stress than the year 2018-19.

\section{Leaf area index (LAI) and Leaf area duration (LAD)}

Leafarea index (LAI) followed an exponential relation with days after sowing (Fig. 1). LAI under CT and NT showed variable response over the years. Maximum LAI $\left(\mathrm{LAI}_{\max }\right.$ ) was higher in CT (12.7\%) than NT during 2017-18 whereas it was higher in NT (8.8\%) than CT during 201819. Crop residue mulch (CRM) improved the LAI during both the years (by 6.5\% and 10\% in 2017-18 and 2018-19, respectively). Higher LAI ${ }_{\max }$ in CT (2017-18) or NT (2018$19)$ is well correlated with higher yields in these treatments (Table2). Higher LAI inCT isinagreement with Gaj ri et al . (1992) while Yin et al. (2016) observed that LAI with standing straw and NT was more than straw incorporated and straw removal treatments of CT. The LAI of wheat increased significantly with increase with increase in $\mathrm{N}$ doses. Averaged over tillage and residue management, $\mathrm{LAI}_{\max }$ with $180 \mathrm{~kg} \mathrm{~N} \mathrm{ha}^{-1}$ was higher than 120 and $60 \mathrm{~kg} \mathrm{~N} \mathrm{ha}^{-1}$ by $44.4 \%$ and $99 \%$, respectively in $2017-18$ and by 25.6 and $79.3 \%$, respectively in 2018-19. Application of $120 \mathrm{~kg} \mathrm{~N}^{-}$ ${ }^{1}$ significantly improved LAI ${ }_{\text {max }}$ than that of $60 \mathrm{~kg} \mathrm{~N} \mathrm{ha}^{-1}$ by $37.8 \%$ and $42.7 \%$, during the year 2017-18 and 2018-19, respectively. This increase in LAI with increase in $\mathrm{N}$ dose was due to increase in cell enlargement (McCree and Davis 1974); increased growth (Jones et al., 1980) and increased photosynthetic activity of leaves (Openheimer, 1960) with increasing $\mathrm{N}$-doses and is in agreement with Cox et al. (1993); Panda et al. (2004) and Pradhan et al. (2014).

The LAD during 2017-18 was higher in CT (by 8.2\%) than that of NT whereas during 2018-19 it was higher in NT (by $9 \%$ ) than that of CT (Fig. 2). CRM could increase the LAD in both the years (by $4 \%$ and $12.8 \%$, in $2017-18$ and 2018-19, respectively) than no-mulch treatment. LAD under 

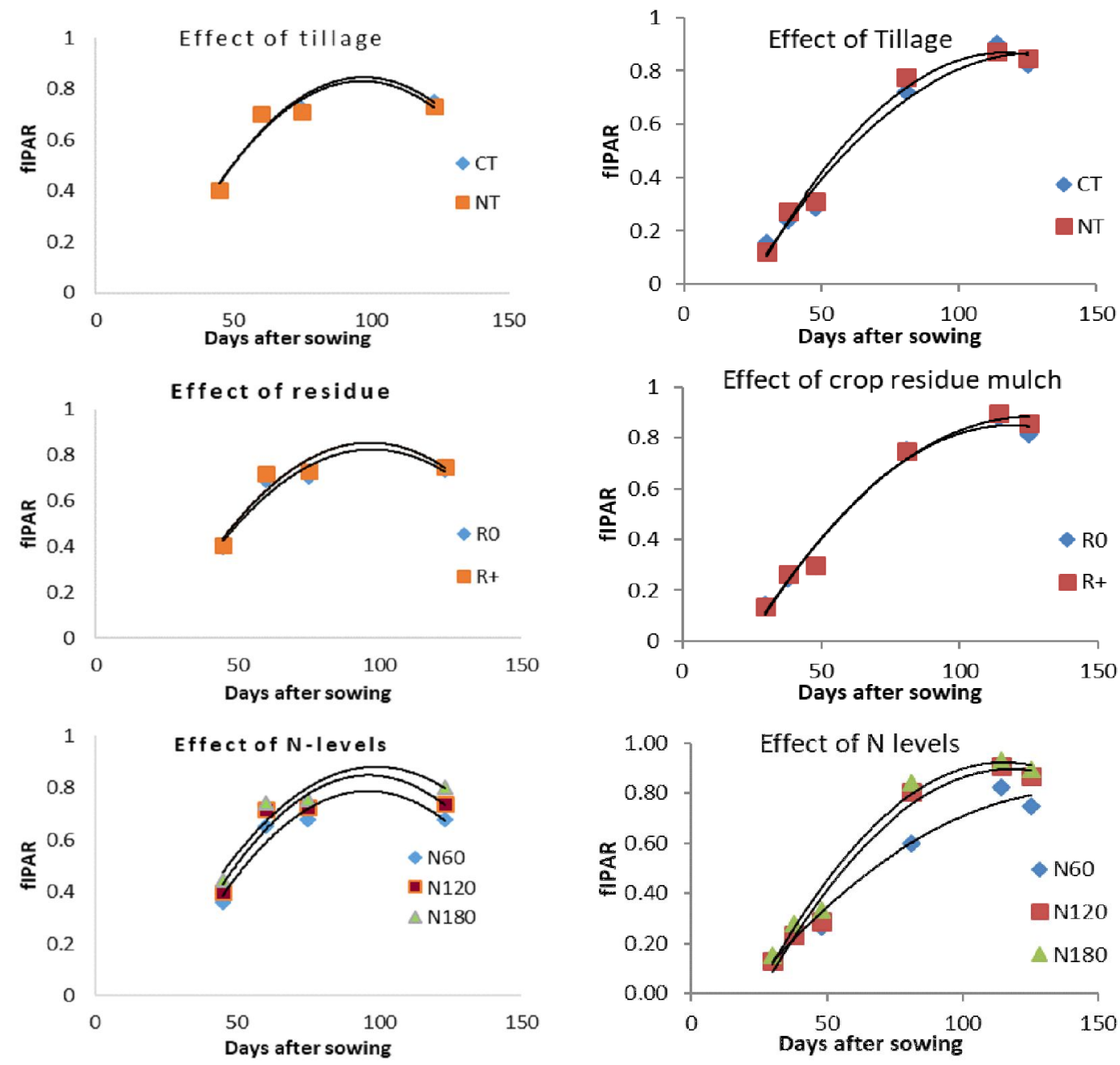

Fig.3: Effect of tillage, crop residue mulch and nitrogen levels on fraction intercepted photosynthetically active radiation (fIPAR) of wheat for 2017-18 and 2018-19

N180 increased over N120 and N60 treatments by 23 and $58 \%$, respectively during $2017-18$ and by 24.9 and $75.2 \%$, respectively during 2018-19. Similarly application of 120 $\mathrm{kg} \mathrm{N} \mathrm{ha}^{-1}$ significantly increased LAD (by 27.9 and $40.3 \%$ in 2017-18 and 2018-19, respectively) than that of $60 \mathrm{~kg} \mathrm{~N}$ ha $^{-1}$.

\section{Extinction coefficient ( $k$ )}

Extinction coefficient $(\mathrm{k})$ varied from 0.46 to 0.59 during 2017-18 and from 0.41 to 0.504 during 2018-19 (Fig. 3), which is within the range of reported $\mathrm{k}$ values (0.410.78) for bread wheat (Yunusa et al., 1993). There was no significant difference among tillage and residue management with respect to extinction coefficient but lower k values due to application of residues indicate the tendency of more horizontal leaf distributions over no mulch treatments. Averaged over tillage and residue management, extinction coefficient due to 60,120 and $180 \mathrm{~kg} \mathrm{~N} \mathrm{ha}^{-1}$ were $0.59,0.53$ and 0.46 , respectively during $2017-18$ while during 2018 19 , it was $0.46,0.46$ and 0.44 , respectively. Decrease in $\mathrm{k}$ with increasing $\mathrm{N}$ level is in agreement with earlier findings (Brekke et al., 2011; Bassu et al., 2011; Saha etal., 2015).

\section{Grain yield and biomass yield of wheat}

During the years 2018-19 the average grain as well as biomass yields (Table 2) was higher than that of the year 2017-18 due to more rainfall and lower temperature during crop growth seasons of 2018-19. Although, grain and biomass yield were not significantly influenced by either tillage or CRM but was significantly influenced by N-levels during both the years of study. Under N180 respectively 7.2 and $35.5 \%$ higher grain yield and 9.9 and $35.8 \%$ higher biomass yields were recorded over N120 and N60 during the year 2017-18. Similarly, during 2018-19 10.1 and 41.1\% higher grain yields and 7.9 and $33 \%$ higher biomass yields were recorded under N180 than $\mathrm{N} 120$ and N60, respectively. 
Table 2: Grain yield and Biomass yield of wheat as influenced by tillage, residue and nitrogen management

\begin{tabular}{|c|c|c|c|c|}
\hline \multirow[t]{2}{*}{ Treatment } & \multicolumn{2}{|c|}{ Grain yield $\left(\mathrm{kg} \mathrm{ha}^{-1}\right)$} & \multicolumn{2}{|c|}{ Biomass yield $\left(\mathrm{kg} \mathrm{ha}^{-1}\right)$} \\
\hline & $2017-18$ & 2018-19 & $2017-18$ & 2018-19 \\
\hline \multicolumn{5}{|c|}{ Effect of tillage } \\
\hline $\mathrm{CT}$ & $2778^{\mathrm{A}}$ & $3444^{\mathrm{A}}$ & $6778^{\mathrm{A}}$ & $9624^{\mathrm{A}}$ \\
\hline NT & $2577^{\mathrm{A}}$ & $3630^{\mathrm{A}}$ & $6822^{\mathrm{A}}$ & $10141^{\mathrm{A}}$ \\
\hline \multicolumn{5}{|c|}{ Effect of residues } \\
\hline $\mathrm{R}_{0}$ & $2623^{\mathrm{A}}$ & $3530^{\mathrm{A}}$ & $6794^{\mathrm{A}}$ & $9869^{\mathrm{A}}$ \\
\hline $\mathrm{R}_{+}$ & $2732^{\mathrm{A}}$ & $3545^{\mathrm{A}}$ & $6806^{\mathrm{A}}$ & $9896^{\mathrm{A}}$ \\
\hline \multicolumn{5}{|c|}{ Effect of Nitrogen } \\
\hline $\mathrm{N}_{60}$ & $2220^{\mathrm{C}}$ & $2873^{\mathrm{C}}$ & $5675^{\mathrm{C}}$ & $8320^{\mathrm{C}}$ \\
\hline $\mathrm{N}_{120}$ & $2805^{\mathrm{B}}$ & $3684^{\mathrm{B}}$ & $7017^{\mathrm{B}}$ & $10258^{\mathrm{B}}$ \\
\hline $\mathrm{N}_{180}$ & $3008^{\mathrm{A}}$ & $4054^{\mathrm{A}}$ & $7708^{\mathrm{A}}$ & $11069^{\mathrm{A}}$ \\
\hline \multicolumn{5}{|c|}{ Effect of Tillage $\times$ Residue $\times$ Nitrogen } \\
\hline $\mathrm{CTR}_{0} \mathrm{~N}_{60}$ & $2133^{a}$ & $2783^{a}$ & $5500^{\text {a }}$ & $8500^{\text {a }}$ \\
\hline $\mathrm{CTR}_{0} \mathrm{~N}_{120}$ & $2901^{a}$ & $3256^{\mathrm{a}}$ & $7000^{a}$ & $9728^{a}$ \\
\hline $\mathrm{CTR}_{0} \mathrm{~N}_{180}$ & $3027^{\mathrm{a}}$ & $3978^{a}$ & $7500^{a}$ & $10309^{a}$ \\
\hline $\mathrm{CTR}_{+} \mathrm{N}_{60}$ & $2457^{\mathrm{a}}$ & $3015^{\mathrm{a}}$ & $6000^{a}$ & $8471^{\text {a }}$ \\
\hline $\mathrm{CTR}_{+} \mathrm{N}_{120}$ & $2951^{a}$ & $3729^{a}$ & $7000^{a}$ & $9696^{a}$ \\
\hline $\mathrm{CTR}_{+} \mathrm{N}_{180}$ & $3201^{a}$ & $3902^{a}$ & $7667^{a}$ & $11038^{a}$ \\
\hline $\mathrm{NTR}_{0} \mathrm{~N}_{60}$ & $2118^{a}$ & $2698^{a}$ & $5267^{\text {a }}$ & $7663^{a}$ \\
\hline $\mathrm{NTR}_{0} \mathrm{~N}_{120}$ & $2683^{a}$ & $4095^{\mathrm{a}}$ & $7333^{a}$ & $11335^{a}$ \\
\hline $\mathrm{NTR}_{0} \mathrm{~N}_{180}$ & $2879^{a}$ & $4366^{a}$ & $8167^{\text {a }}$ & $11678^{a}$ \\
\hline $\mathrm{NTR}_{+} \mathrm{N}_{60}$ & $2171^{a}$ & $2996^{a}$ & $5933^{a}$ & $8646^{a}$ \\
\hline $\mathrm{NTR}_{+} \mathrm{N}_{120}$ & $2685^{\mathrm{a}}$ & $3656^{\mathrm{a}}$ & $6733^{a}$ & $10273^{a}$ \\
\hline $\mathrm{NTR}_{+} \mathrm{N}_{180}$ & $2926^{\mathrm{a}}$ & $3971^{\text {a }}$ & $7500^{a}$ & $11249^{a}$ \\
\hline
\end{tabular}

\# Values in a column followed by same letters are not significantly different at $\mathrm{p}<0.05$ as per DMRT ; The uppercase letters and the lower case letters are used for comparing main plot and subplot effects, respectively

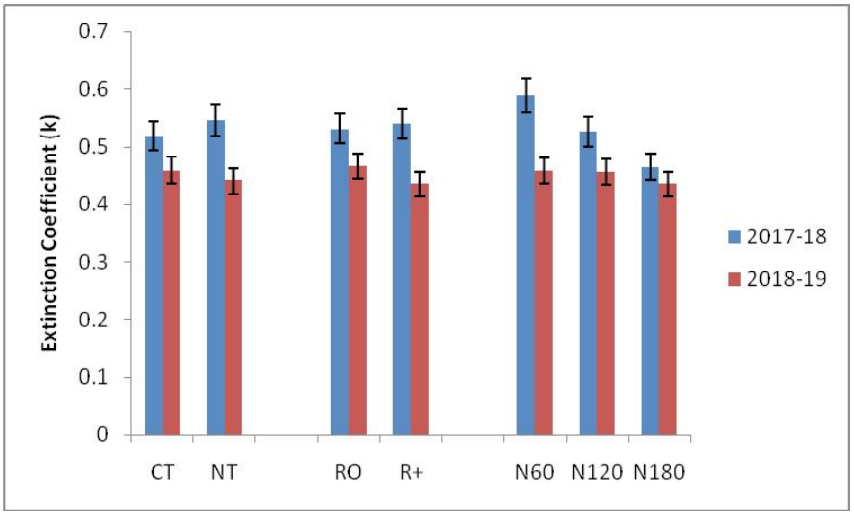

Fig.4: Extinction coefficient of wheat as influenced by tillage, crop residue mulch and $\mathrm{N}$ levels
Under N120, there was significant increase in grain yield (by $26.3 \%$ during $2017-18$ and by $28.2 \%$ during $2018-19$ ) and biomass yield (by $23.6 \%$ during $2017-18$ and $23.3 \%$ during 2018-19) over N60 during both the years. However, contrary to the present study, it was reported that conservation agriculture practice could increase yield from second year onwards (Jat et al., 2014) or after three years of cropping (Zhang et al., 2009) by some workers. The interaction among tillage, residue and $\mathrm{N}$-doses were not significant on grain and biomass yield of wheat.

Fraction intercepted photosyntheticaly active radiation (fIPAR)

The temporal variation of fIPAR for the years 2017 - 
Table 3: TIPAR and RUE of wheat as influenced by tillage, residue and nitrogen management

\begin{tabular}{|c|c|c|c|c|}
\hline \multirow[t]{2}{*}{ Treatment } & \multicolumn{2}{|c|}{ TIPAR $\left(\mathrm{MJ} \mathrm{m}^{-2}\right)$} & \multicolumn{2}{|c|}{$\left.\operatorname{RUE}\left(\mathrm{g} \mathrm{MJ}^{-1}\right)\right)$} \\
\hline & $2017-18$ & 2018-19 & $2017-18$ & 2018-19 \\
\hline \multicolumn{5}{|c|}{ Effect of tillage } \\
\hline $\mathrm{CT}$ & 663.4 & 591.6 & $1.02^{\mathrm{A}}$ & $1.62^{\mathrm{A}}$ \\
\hline NT & 674.3 & 606.3 & $1.01^{\mathrm{A}}$ & $1.67^{\mathrm{A}}$ \\
\hline \multicolumn{5}{|c|}{ Effect of residues } \\
\hline $\mathrm{R}_{0}$ & 647.9 & 592.4 & $1.04^{\mathrm{A}}$ & $1.66^{\mathrm{A}}$ \\
\hline $\mathrm{R}_{+}$ & 689.8 & 605.5 & $0.99^{\mathrm{A}}$ & $1.63^{\mathrm{A}}$ \\
\hline \multicolumn{5}{|c|}{ Effect of Nitrogen } \\
\hline $\mathrm{N}_{60}$ & 608.2 & 529.7 & $0.93^{\mathrm{C}}$ & $1.57^{\mathrm{B}}$ \\
\hline $\mathrm{N}_{120}$ & 693.0 & 618.2 & $1.02^{\mathrm{B}}$ & $1.66^{\mathrm{A}}$ \\
\hline $\mathrm{N}_{180}$ & 705.3 & 649.1 & $1.09^{\mathrm{A}}$ & $1.70^{\mathrm{A}}$ \\
\hline \multicolumn{5}{|c|}{ Effect of Tillage $\times$ Residue $\times$ Nitrogen } \\
\hline $\mathrm{CTR}_{0} \mathrm{~N}_{60}$ & 610.8 & 540.2 & $0.90^{\mathrm{a}}$ & $1.57^{\mathrm{a}}$ \\
\hline $\mathrm{CTR}_{0} \mathrm{~N}_{120}$ & 660.5 & 599.3 & $1.06^{\mathrm{a}}$ & $1.62^{\mathrm{a}}$ \\
\hline $\mathrm{CTR}_{0} \mathrm{~N}_{180}$ & 693.5 & 617.3 & $1.08^{\mathrm{a}}$ & $1.67^{\mathrm{a}}$ \\
\hline $\mathrm{CTR}_{+} \mathrm{N}_{60}$ & 620.6 & 554.7 & $0.97^{\mathrm{a}}$ & $1.53^{\mathrm{a}}$ \\
\hline $\mathrm{CTR}_{+} \mathrm{N}_{120}$ & 669.2 & 595.0 & $1.05^{\mathrm{a}}$ & $1.63^{\mathrm{a}}$ \\
\hline $\mathrm{CTR}_{+} \mathrm{N}_{180}$ & 725.9 & 643.3 & $1.06^{\mathrm{a}}$ & $1.72^{\mathrm{a}}$ \\
\hline $\mathrm{NTR}_{0} \mathrm{~N}_{60}$ & 585.7 & 483.4 & $0.90^{\mathrm{a}}$ & $1.59^{\mathrm{a}}$ \\
\hline $\mathrm{NTR}_{0} \mathrm{~N}_{120}$ & 650.5 & 630.4 & $1.13^{\mathrm{a}}$ & $1.80^{\mathrm{a}}$ \\
\hline $\mathrm{NTR}_{0} \mathrm{~N}_{180}$ & 686.2 & 684.1 & $1.19^{\mathrm{a}}$ & $1.71^{\mathrm{a}}$ \\
\hline $\mathrm{NTR}_{+} \mathrm{N}_{60}$ & 615.5 & 540.5 & $0.96^{\mathrm{a}}$ & $1.60^{\mathrm{a}}$ \\
\hline $\mathrm{NTR}_{+} \mathrm{N}_{120}$ & 792.0 & 647.9 & $0.85^{\mathrm{a}}$ & $1.59^{\mathrm{a}}$ \\
\hline $\mathrm{NTR}_{+} \mathrm{N}_{180}$ & 715.8 & 651.8 & $1.05^{\mathrm{a}}$ & $1.73^{\mathrm{a}}$ \\
\hline
\end{tabular}

\# Values in a column followed by same letters are not significantly different at $\mathrm{p}<0.05$ as per DMRT ; The uppercase letters and the lower case letters are used for comparing main plot and subplot effects, respectively.

18 and 2018-19 (Fig. 3) followed a trend similar to that of LAI. This finding is in agreement with Serrano et al. (2000). The maximum fIPAR under CT was higher (by $2.7 \%$ in $2017-18$ and $3.3 \%$ in 2018-19) than that under NT. Similarly maximum fIPAR under CRM was higher than no mulch treatments by 2.3 and $2.0 \%$ in 2017-18 and 2018-19, respectively. This showed that application of crop residue mulch could enhance radiation interception probably due to better leaf area productions. With increase in N-doses, maximum fIPAR increased in both the years. This finding is in agreement with Pradhan et al. (2018).

Total Intercepted Photosynthetically Active Radiation (TIPAR) and Radiation Use Efficiency (RUE) of Wheat

The TIPAR and RUE of wheat was not significantly affected by tillage and residue managements but increased significantly with increasing N-doses (Table 3). TIPAR in N180 was higher than N60 by 16 and $22.5 \%$ in 2017-18 and 2018-19, respectively. Similarly, RUE in N180 was higher than N60 by 17.2 and $8.3 \%$ during 2017-18 and 2018-19, respectively. During the year 2017-18, RUE under N180 was significantly higher than that of $\mathrm{N} 120$ by $6.9 \%$ whereas during the year 2018-19, there was no significant difference in RUE due to N120 and N180. Higher TIPAR with increasing $\mathrm{N}$-level was due to higher LAI at higher N-levels (Bassu et al., 2011; Pradhan et al., 2018). Higher RUE at higher Nlevels is in agreement with Pradhan et al. (2014) which may be due to higher LAD at higher N-levels. The interaction of tillage, residue and $\mathrm{N}$-management was not significant on TIPAR and RUE of wheat in both the years. 

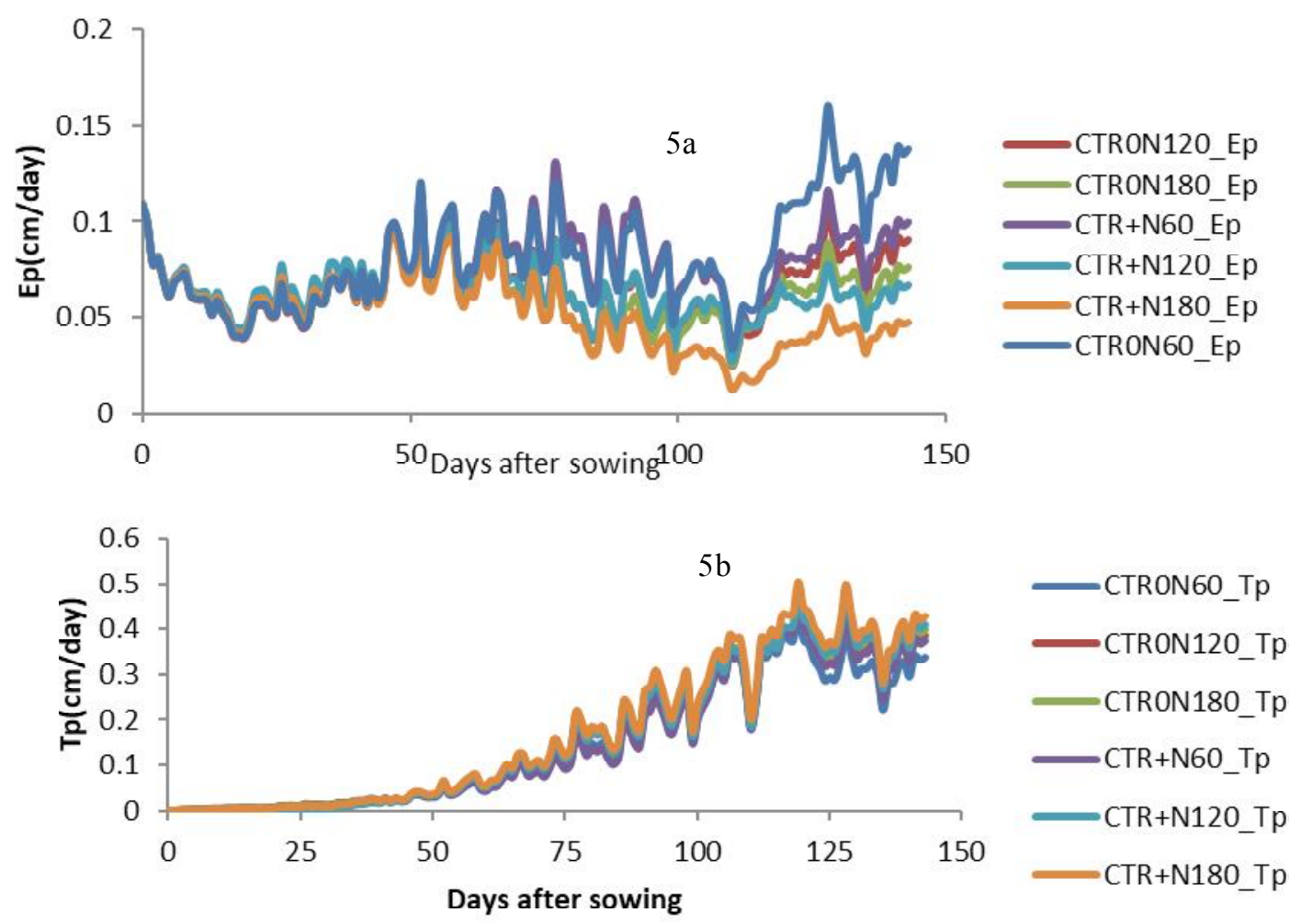

Fig.5: Potential evaporation (Ep)(5a) and Potential transpiration (Tp) (5b) rate ( $\left.\mathrm{cm} \mathrm{day}^{-1}\right)$ of wheat as influenced by crop residue mulch and $\mathrm{N}$ levels under conventional tillage during the year 2018-19
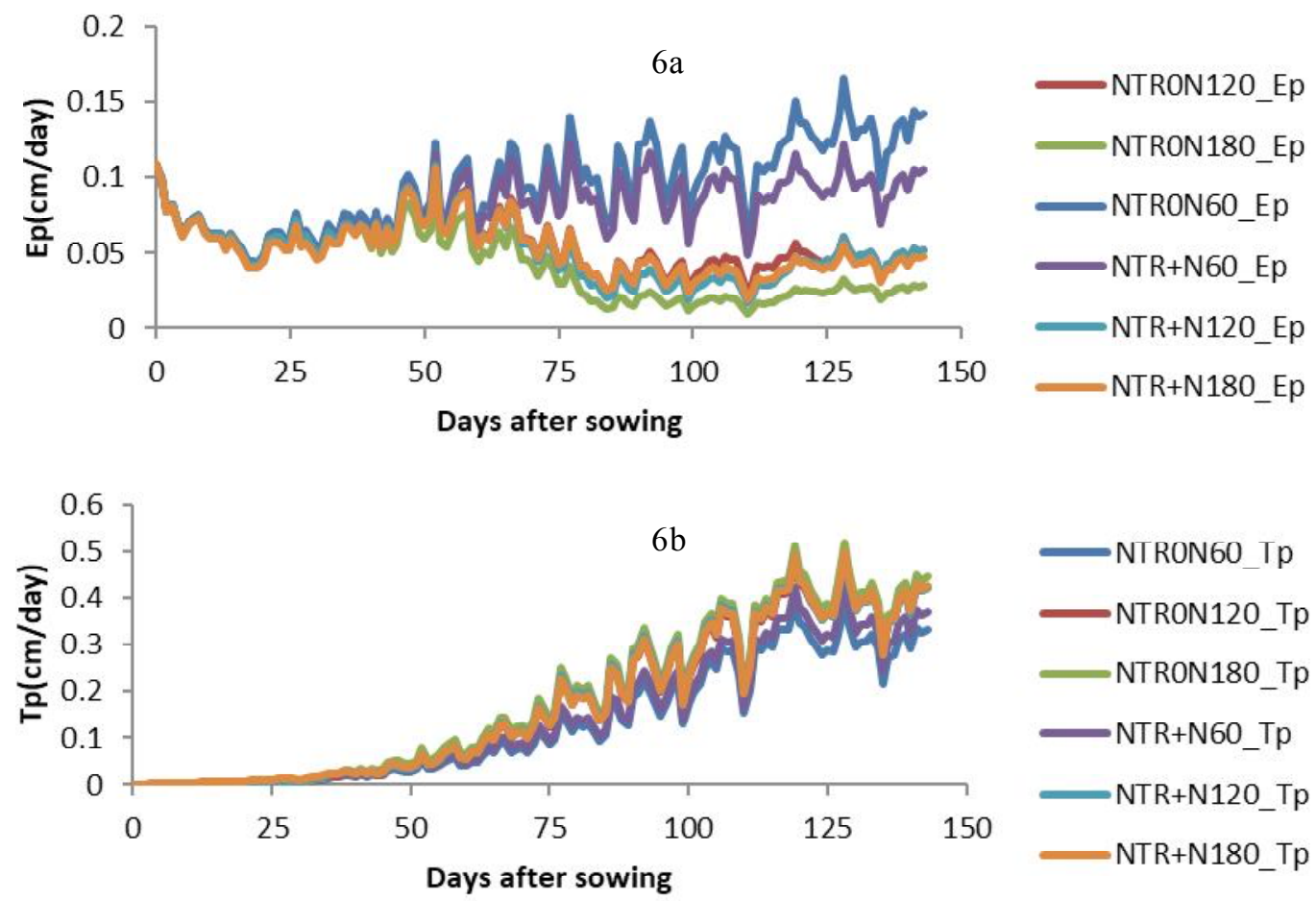

Fig.6: Potential evaporation (Ep) (6a) and Potential transpiration (Tp) rate (cm day $\left.{ }^{-1}\right)(6 \mathrm{~b})$ of wheat as influenced by crop residue mulch and $\mathrm{N}$ levels under No tillage during the year 2018-19. 


\section{Soil evaporation (Ep) and crop transpiration rate (Tp)}

Temporal variation in soil evaporation (Ep) and crop transpiration (Tp) under different tillage, residue and $\mathrm{N}$ management for the year 2018-19 is depicted in Fig 5 and Fig. 6, respectively. Averaged over residue and Nmanagement, Ep under NT was less (by 6\%) and Tp was higher (by $2.6 \%$ ) than that of CT. Similarly averaged over tillage and $\mathrm{N}$-management Ep was reduced by $5.6 \%$ and $\mathrm{Tp}$ was increased by $2.4 \%$ under CRM than that of no mulch treatments. Under crop residue mulch lower evaporation loss was due to less radiation interception at the soil surface and higher transpiration was due to better hydrothermal regime and better crop growth. With the increase in N-dose, potential evaporation decreased while the potential transpiration increased. This may be attributed to the fact that a nitrogen-deficient crop has high evaporation/ transpiration ratio associated with small canopies (Caviglia and Sadras, 2001; Norton and Wachsmann, 2006).

\section{CONCLUSION}

From this study it may be concluded that residue mulching is an effective strategy to improve the crop transpiration (Tp) by reducing the soil evaporation (Ep) losses and thus can improve yield of wheat. This has also potential to increase the maximum leaf area index and leaf area duration. With the increase in $\mathrm{N}$ dose there was increase in LAI, LAD, TIPAR, grain yield, RUE and Tp but decrease in Ep. So, conservation agricultural practices i.e., No tillage with crop residue mulching and $150 \%$ of the recommended dose of nitrogen has the potential to improve radiation interception, radiation use efficiency and grain yield of wheat in the North-west plain region of India.

\section{ACKNOWLEDGEMENT}

The first author acknowledges the help received from IARI in the form of Fellowship during the study period. The logistic support received from the Director, IARI during the study period is thankfully acknowledged.

\section{REFERENCES}

Allen, R.G., Pereira, L.S., Raes, D. and Smith, M. (1998). “Crop evapotranspiration-Guidelines for computing crop water requirements-FAO Irrigation and drainage paper 56". FAO Rome 300, D05109.

Bassu, S., Giunta, F. and Motzo, R. (2011). Effects of sowing date and cultivar on radiation use efficiency in durum wheat. Crop Pasture Sci., 62 (1): 39-47.
Boatman, N.D., Parry, H.R., Bishop, J.D. and Cuthbertson, A.G. (2007). Impacts of agricultural change on farmland biodiversity in the UK. Biodiversity under Threat, 132 .

Brekke, B., Edwards, J. and Knapp, A. (2011). Selection and adaptation to high plant density in the Iowa stiff stalk synthetic maize (Zea mays L.) population: II. Plant morphology. Crop Sci., 51(6): 2344-2351.

Caviglia, O.P. and Sadras, V.O. (2001). Effect of nitrogen supply on crop conductance, water-and radiation-use efficiency of wheat. Field Crops Res., 69(3): 259-266.

Cox, W.J., Kalonge, S., Cherney, D.J.R. and Reid, W.S. (1993). Growth, yield, and quality of forage maize under different nitrogen management practices. Agron. J., 85(2):341347.

Das, T.K., Saharawat, Y.S., Bhattacharyya, R., Sudhishri, S., Bandyopadhyay, K.K., Sharma,A.R. and Jat, M.L. (2018) Conservation agriculture effects on crop and water productivity, profitability and soil organic carbon accumulation under a maize-wheat cropping system in the North-western Indo-Gangetic Plains. Field Crops Res., 215, 222-231.

Friedrich, T. and Gustafson, D. (2007) Conservation agriculture: synergies of resource-conserving technologies in ricebased systems, Articulos Generals.

Gajri, P.R.,Arora, V.K. and Prihar, S.S. (1992). Tillage management for efficient water and nitrogen use in wheat following rice. Soil Tillage Res., 24(2): 167-182.

Goyal,A., Das, D., Sehgal, V., Vashisth,A., Datta, S., Mukherjee, J. and Singh, R. (2018). Effect of row direction and cultivar on micrometeorological and biophysical parameters of oil seed Brassica. J. Agrometeorol., 20: 85-91.

Jat, R.K., Sapkota, T.B., Singh, R.G., Jat, M.L., Kumar, M. and Gupta, R.K. (2014). Seven years of conservation agriculture in a rice-wheat rotation of Eastern Gangetic Plains of South Asia: yield trends and economic profitability. Field Crops Res., 164: 199-210.

Jones, M.B., Leafe, E.L. and Stiles, W. (1980). Water stress in field grown perennial ryegrass. Its effect on growth, canopy photosynthesis and transpiration. Annals Appl. Biol., 96(1): 87-101.

Kassam,A.H., Friedrich, T. andDerpsch, R. (2010). Conservation agriculture in the $21^{\text {st }}$ century: A paradigm of sustainable agriculture. Euro. Congress Conserv. Agric., 10: 4-6. 
McCree, K.J. and Davis, S.D. (1974). Effect of Water Stress and Temperature on Leaf Size and on Size and Number of Epidermal Cells in Grain Sorghum 1. Crop Sci., 14(5): $751-755$.

Monsi, M. and Saeki, T. (1953). The light factor in plant communities and its significance for dry matter production. Japanese J. Bot., 14(1): 22-52.

Norton, R.M., and Wachsmann, N.G. (2006). Nitrogen use and crop type affect the water use of annual crops in southeastern Australia. Aust. J. Agric. Res., 57(3): 257-267.

Oppenheimer, H.R. (1960). Adaptation to drought: Xerophytism. 105-138. Arid Zone Res. XV. Plant-water relationships in arid and semi-arid conditions.

Panda, R.K., Behera, S.K. and Kashyap, P.S. (2004). Effective management of irrigation water for maize under stressed conditions. Agric. Water Manage., 66(3): 181-203.

Pradhan, S., Sehgal, V.K., Sahoo, R.N., Bandyopadhyay, K.K. and Singh, R. (2014). Yield, water, radiation and nitrogen use efficiencies of wheat (Triticum aestivum) as influenced by nitrogen levels in a semi-arid environment. Indian J. Agron., 59(2): 267-275.

Pradhan, S., Bandyopadhyay, K.K., Panigrahi, P. and Manikandan, N. (2018). Effect of tillage, residue and nitrogen management on radiation interception and radiation use efficiency of wheat in a semi-arid environment. J. Agrometeorol., 20(2): 149-152.

Pragya, D., Sehgal, V., Das, T. and Mukherjee, J. (2018). Evaluation of conservation agriculture practices for radiation interception and biophysical properties in rice-mustard cropping system. Mausam, 69(4): 607614.
Ritchie, J.T. (1972) Model for predicting evaporation from a row crop with incomplete cover. Water Resour. Res., 8(5): 1204-1213.

Saha, S., Sehgal, V.K., Chakraborty, D. and Pal, M. (2015). Atmospheric carbon dioxide enrichment induced modifications in canopy radiation utilization, growth and yield of chickpea(Cicer arietinum L.). Agric. Forest Meteorol., 202: 102-111.

Serrano, L., Filella, I. and Penuelas, J. (2000). Remote sensing of biomass and yield of winter wheat under different nitrogen supplies. Crop Sci., 40(3): 723-731.

Wakchaure, G.C., Choudhary, R.L., Kaledhonkar, M.J. and Bal, S.K. (2015). Effect of precision land levelling on microenvironment and sorghum productivity in water scarce Deccan region. J. Agrometeorol., 17(2): 149157.

Yin, W., Chai, Q., Guo, Y., Feng, F., Zhao, C., Yu, A. and Hu, F. (2016). Analysis of Leaf Area Index Dynamic and Grain Yield Components of Intercropped Wheat and Maize under Straw Mulch Combined with Reduced Tillage in Arid Environments. J. Agric. Sci., 8(4): 26-42.

Yunusa, I.A.M., Siddique, K.H.M., Belford, R.K. and Karimi, M.M. (1993). Effect of canopy structure on efficiency of radiation interception and use in spring wheat cultivars during the pre-anthesis period in a Mediterranean-type environment. Field Crops Res., 35(2): 113-122.

Zhang, X., Li, H., He, J., Wang, Q. and Golabi, M.H. (2009) Influence of conservation tillage practices on soil properties and cropyields for maize and wheat cultivation in Beijing, China. Soil Res., 47(4): 362-371. 